\title{
Assessment of waste clays in the Qusseir region of east central Egypt for production of lightweight bricks
}

\author{
Esmat Abu El-Anwar ${ }^{1}$, Hamed Mekky ${ }^{1}$, Wael Abdelwahab ${ }^{1 *}$ (D) and Mohamed Elmaghraby ${ }^{2}$
}

\begin{abstract}
Background: Egyptian Upper Cretaceous waste clay samples from Yunis Mines, Qusseir vicinity, Eastern Desert, were investigated for their chemical and mineralogical compositions as well as for firing. These investigations were carried out to assess the suitability to use the waste clays for the production of lightweight bricks. X-ray fluorescence (XRF), scanning electron microscopy (SEM), X-ray diffraction (XRD), and Fourier transform infrared (FTIR) techniques were applied for characterizing chemical and mineral compositions of the raw clays. On the other side, densification parameters of the fired samples up to $1100{ }^{\circ} \mathrm{C}$ were examined by using Archimedes water-saturation methods and by determining the density and crushing strength of the fired bodies.

Results: Two types of concrete were prepared using different grain sizes: coarse and a mix of coarse and fine aggregates. Concrete batches were prepared, and the mechanical strength and the bulk density were determined. Mineralogically, the waste samples consist of montmorillonite as the predominant clay mineral, with quartz, calcite, fluorapatite, anhydrite, and pyrite as impurities. Bulk density and apparent porosity of the fired clay sample at $1100{ }^{\circ} \mathrm{C}$ were $0.89 \mathrm{~g} / \mathrm{cm}^{3}$ and $67.19 \%$, respectively, while the bulk density of the two types of concrete range from $0.76 \mathrm{~g} / \mathrm{cm}^{3}$ in coarse type with no fines to $0.90 \mathrm{~g} / \mathrm{cm}^{3}$ in the coarse with $20 \%$ fine fraction. The crushing strength of both types is $25 \mathrm{~kg} / \mathrm{cm}^{2}$ for coarse type and $45 \mathrm{~kg} / \mathrm{cm}^{2}$ for coarse and fine types, respectively.

Conclusions: The results showed that the data provides a useful application of waste clay ramps of ancient Yunis mining tunnels in Qussier area with an additional mean to assess their suitability for the production of lightweight brick concretes to reduce density and their relatively good strength in modern buildings for nonloading building units and to enhance the thermal insulation of buildings.
\end{abstract}

Keywords: Clays, Montmorillonite, Lightweight, Concrete

\section{Background}

Clay deposits are widely distributed within many geological formations from Carboniferous to recent age. They are located in the region of Nile Valley and Delta, as well as in the Western and Eastern Desert of Egypt. Most of these deposits are used for the applications in many ceramic industries, for example, whiteware, refractories, heavy clay products, and Portland cement (Hanna and Stoops 1977; Said 1990; Youssef 2008). Clays are classified according to their particle size, mineral and chemical compositions, and other properties

\footnotetext{
*Correspondence: dr.wael.nrc@gmail.com; wa.wahab@nrc.sci.eg ${ }^{1}$ Geological Sciences Department, National Research Centre, Al-Behoos Street, Dokki, Cairo 12622, Egypt

Full list of author information is available at the end of the article
}

(Grim 1962, 1968; Grimshaw 1971; Norton 1969; Konta 1979, Burst 1991). Many authors indicated that kaolinite-rich clay materials are refractory with a high vitrification range, low plasticity, white-to-buff burning colour and a low-drying and firing shrinkage. Moreover, montmorillonite-rich clays are non-refractory with low vitrification ranges, high plasticity, buff-to-red burning colour, and a high-drying and firing shrinkage. In contrast, illite-rich clays are falling between kaolinitic and montmorillonitic clays and exhibit wide variations. Lightweight clay aggregates may be produced by firing pellets of low-grade montmorillonite-rich clays with or without adding to the vitrification range. After firing, the clay pellets swell or bloat owing to gas releases within the firing bodies during the liquid phase. On cooling, 


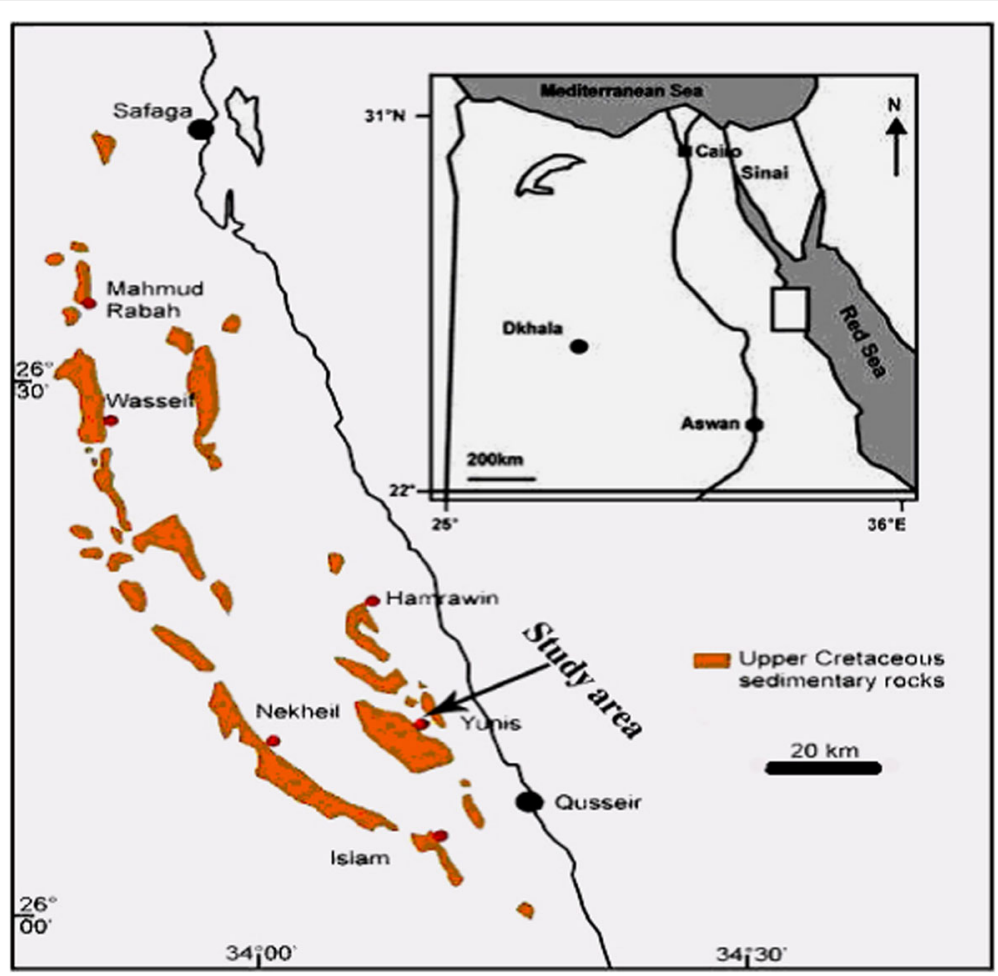

Fig. 1 Location map of the studied area

(a)

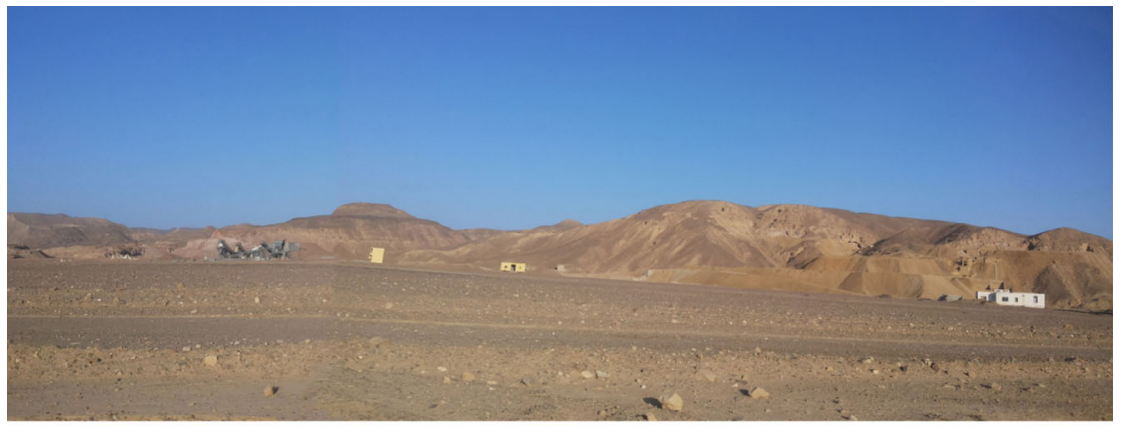

(b)

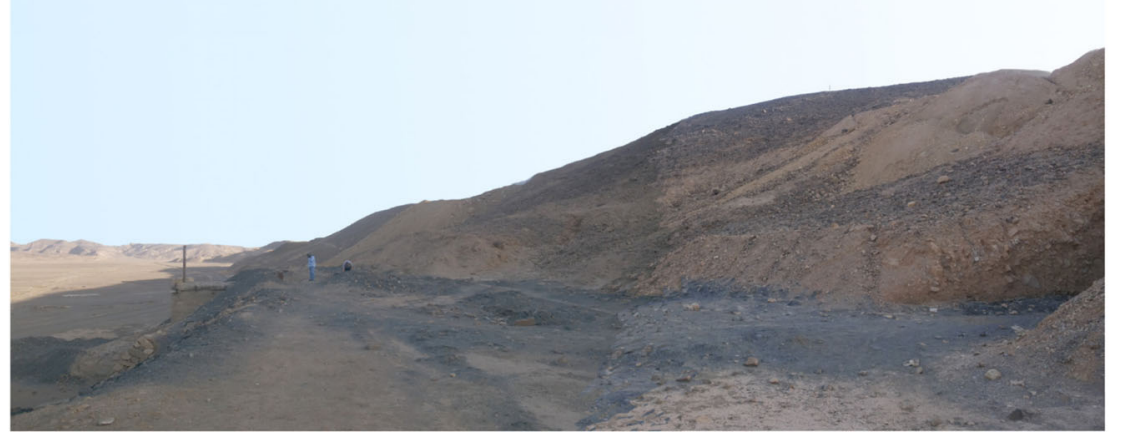

Fig. 2 Field photography of the studied area. a Recent Yunis active mining surface quarry. $\mathbf{b}$ Waste clay ramp of Yunis abandoned mining tunnels 
Table 1 Chemical analyses of the used sample in weight \%

\begin{tabular}{lcccccccccccc}
\hline $\mathrm{SiO}_{2}$ & $\mathrm{Al}_{2} \mathrm{O}_{3}$ & $\mathrm{Fe}_{2} \mathrm{O}_{3}{ }^{*}$ & $\mathrm{TiO}_{2}$ & $\mathrm{MnO}$ & $\mathrm{CaO}$ & $\mathrm{MgO}$ & $\mathrm{Na}_{2} \mathrm{O}$ & $\mathrm{K}_{2} \mathrm{O}$ & $\mathrm{P}_{2} \mathrm{O}_{5}$ & $\mathrm{SO}_{3}$ & $\mathrm{LOI}$ & $\mathrm{Total}$ \\
\hline 21.27 & 7.51 & 1.98 & 0.24 & 0.02 & 15.2 & 0.82 & 0.24 & 0.45 & 4.54 & 4.81 & 42.90 & 99.98 \\
\hline
\end{tabular}

*Total iron as ferric oxide

these low-grade montmorillonite clays conserve the cellular texture, and lightweight aggregate is obtained (Serry et al. 1985; Konta 1995; Karaman et al. 2006; Bernhardt et al. 2013; Ismail et al. 2016, Ismail et al. 2018; Risdanareni et al. 2017).

Many authors have studied the effect of using a pore-forming agent to increase the porosity of the ceramic body such as Duchan and Kopar (2001), Chemani and Chemani (2013), and Ismail et al. (2016). Others studied the replacement of cement with lighter materials, e.g. Mashaly et al. $(2016,2018)$, Bian et al. (2012) and Pelisser et al. (2012). Also, clay and pore-forming agent are shaped insulating refractory bricks with a true porosity of more than $45 \%$ and a service temperature of at least $800{ }^{\circ} \mathrm{C}$ (Grimshaw 1971; Sargeant and Stone 1981; Courtault et al. 1983; Routschka 1997).

The aim of the present work is to study the mineral and chemical compositions and the properties of the fired, carbonaceous, clay-rich shale at the Yunis mines at Qusseir region (Fig. 1) to reveal their suitability for the production of lightweight bricks, that improve the thermal insulation of buildings.

\section{Methods}

The material used in this work is waste clay from Yunis mines, which is located south of the Hamrawin area and $12 \mathrm{~km}$ from Qusseir-Safaga Asphaltic Road to the west. The chosen area is located at longitudes $34^{\circ} 03^{\prime} 12^{\prime \prime}$ and $34^{\circ} 03^{\prime} 24^{\prime \prime} \mathrm{E}$ and latitudes $26^{\circ} 11^{\prime} 27^{\prime \prime}$ and $26^{\circ} 11^{\prime} 37^{\prime \prime}$ $\mathrm{N}$ (Fig. 1). Upper Cretaceous in the Qusseir shales have a widespread distribution and are associated with the Egyptian phosphate mining zones. These shales occur as parts of a surface and subsurface sedimentary succession that ranges in age from Carboniferous to Eocene. Huge amounts of waste clays are located around Yunis from the abandoned mining tunnels and recent surficial (Fig. 2). Representative samples of these waste clays were investigated to determine their applicability for the production of lightweight bricks after firing at up to $1100{ }^{\circ} \mathrm{C}$.

The chemical and mineralogical compositions of these clays were studied using XRF, XRD, FTIR, and SEM techniques. The chemical composition of the studied samples was determined by using an Axios Sequential WD_XRF Spectrometer, PAnalytical 2005 in the National Research Center Laboratories, Dokki, Cairo, Egypt. ASTM E 1621 standard guide for elemental analysis by wavelength-dispersive X-ray fluorescence spectrometer and the ASTM D 7348 standard test method for loss on ignition (LOI) on solid combustion were used as guidelines. X-ray diffraction analysis (XRD) was performed on a Philips X-ray diffractometer, Mod. PW 1390, with $\mathrm{Ni}$-filtered $\mathrm{Cu}-\mathrm{Kd}$ radiation. The morphology and the microstructure of the samples were characterized with SEM coupled with energy-dispersive spectroscopy EDAX (SEM Model Quanta FEG 250) carried out in the National Research Center Laboratories. FTIR absorption spectra were recorded by Elmer-783 double-beam dispersion spectrophotometer using standard $\mathrm{KBr}$ tablets. Three hundred milligram $\mathrm{KBr}$ was homogenized with 1 to $2 \mathrm{mg}$ of the sample in a vibration mill and evacuated, and the

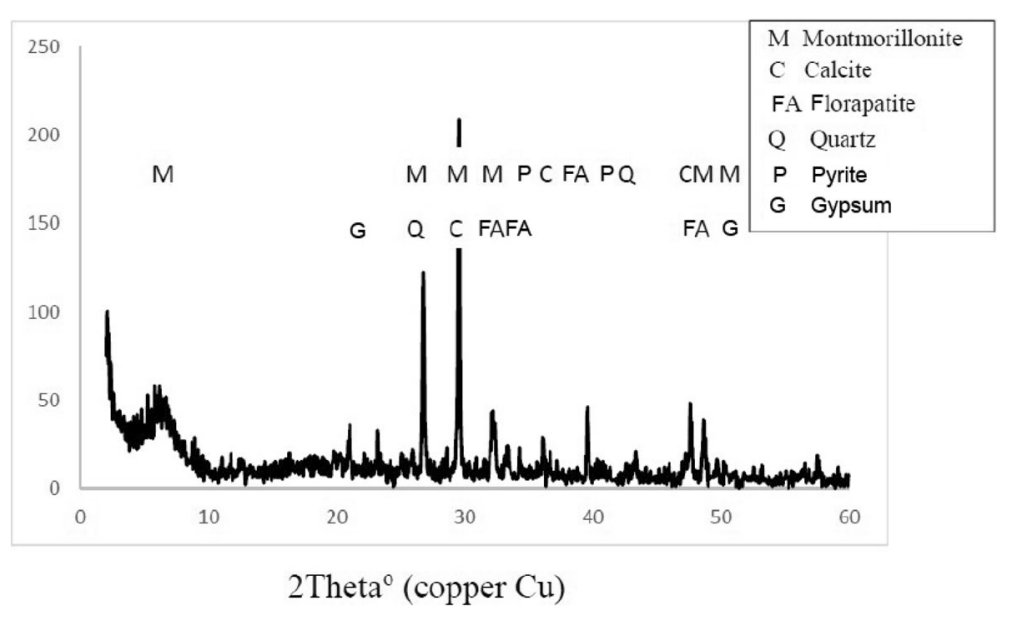

Fig. 3 XRD pattern of raw clay technological sample 
(a)

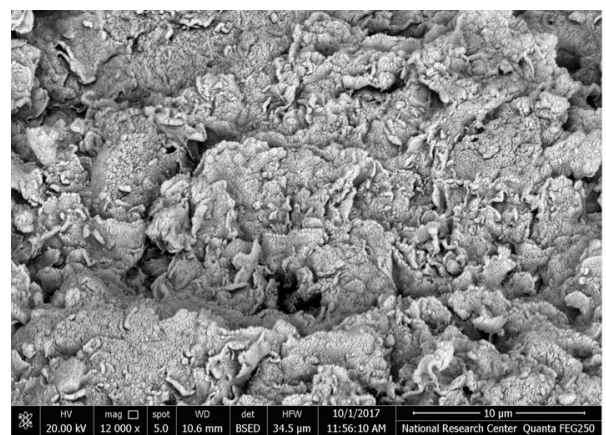

(b)

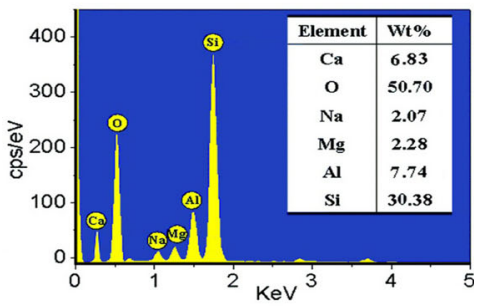

Fig. 4 SEM and EDAX of the raw clay. a Scanning electron micrograph showing a well-crystallized montmorillonite with well-developed "oak leaf" and cellular morphology with tightly interwoven flakes. $\mathbf{b}$ EDAX analysis of Ca-montmorillonite

tablets were then pressed for $5 \mathrm{~min}$ under pressure of $10 \mathrm{MPa}$. The recording time was $20 \mathrm{~min}$, and the range is $4000-400 \mathrm{~cm}^{-1}$.

The preparation of lightweight brick regime starts with the firing of a crushed representative waste clay sample at $1100{ }^{\circ} \mathrm{C}$ and then broke up using a jaw crusher until obtaining a grain size ranging from 2 to $10 \mathrm{~mm}$ with minimum amounts of finer-grained material. Two mixes of concrete were prepared using two different grain sizes of the fired waste clay grains: the first mix consisted of coarse grains ranged from 2 to $10 \mathrm{~mm}$ with no fines, and the second mix composed of coarse grains ( 2 to $10 \mathrm{~mm}$ ) with $10 \%$ finer ones. The percentages of the cement and water were applied as per standard specification (British standard 2028 1968). The concretes were casted into cubic molds with a dimension of $5 \times 5 \times 5 \mathrm{~cm}^{3}$ then demolded after $24 \mathrm{~h}$ and cured in $\sim 95 \%$ humidity chamber for 28 days. The prepared cubes were tested for crushing strength and bulk density according to ASTM C20 2010.

\section{Results}

Characterization of the waste clays

The chemical analysis data from the raw waste clays are summarized in Table 1. It is evident that the clays are calcareous, i.e. rich in $\mathrm{CaO}$ (15.2\%). The weight percent of silica and alumina are 21.27 and 7.51, respectively. Meanwhile, the loss on ignition of the sample was 42.90\%. The percentages of $\mathrm{MgO}, \mathrm{TiO}_{2}, \mathrm{Fe}_{2} \mathrm{O}_{3}$, and $\mathrm{MnO}$ were $0.82,0.24,1.98$, and 0.02 , respectively. $\mathrm{P}_{2} \mathrm{O}_{5}$ and $\mathrm{SO}_{3}$ are recorded at relatively high values $(4.54 \%$ and $4.81 \%$ ) due to the presence of apatite and gypsum, which are confirmed with XRD results (Fig. 3). $\mathrm{Na}_{2} \mathrm{O}$ and $\mathrm{K}_{2} \mathrm{O}$ occurred in minor amounts as 0.24 and $0.45 \%$, respectively.

XRD analysis indicated that the main mineral component of the raw waste clays is montmorillonite, with calcite, fluorapatite, gypsum, and quartz impurities. Pyrite was also detected as in the clay-size fraction.

SEM examination of the studied sample showed the predominance of the clay mineral montmorillonite, which was verified by XRD data (Fig. 3). Figure 4 shows

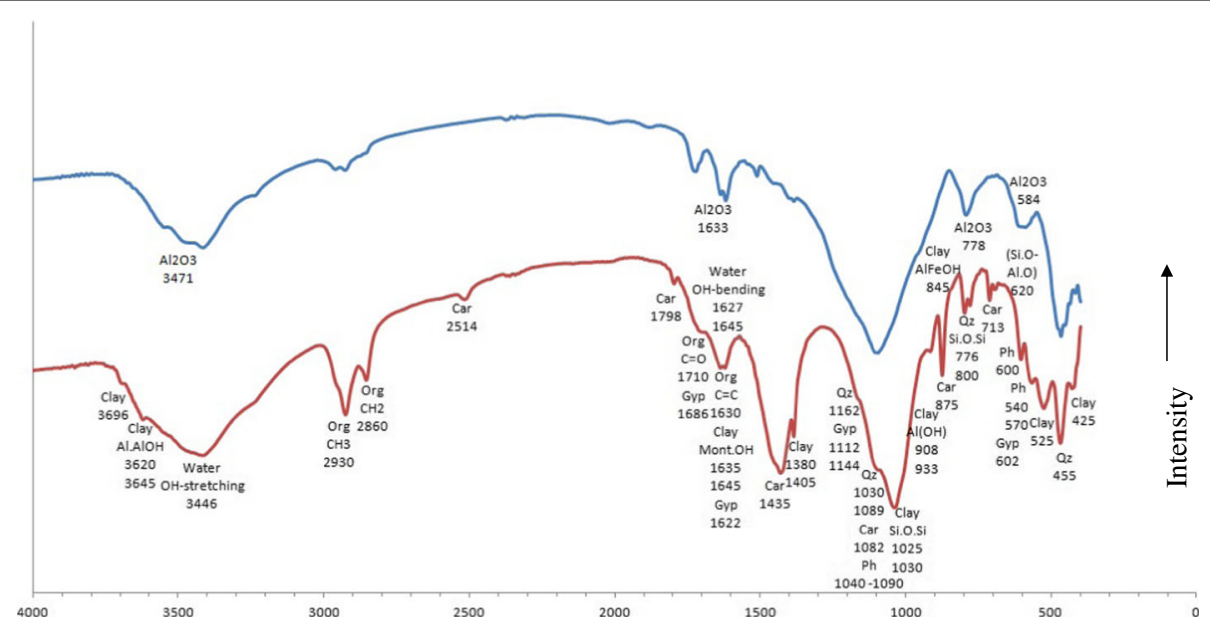

Fig. 5 FTIR spectra recorded for raw clay technological sample (down) and the fired sample (top) 
Table 2 Densification parameter of the fired samples at $1100{ }^{\circ} \mathrm{C}$

\begin{tabular}{lll}
\hline Type of the clay & Bulk density $\left(\mathrm{g} / \mathrm{cm}^{3}\right)$ & Apparent porosity (\%) \\
\hline Raw waste clay & 2.21 & 6.55 \\
Fired waste clay & 0.89 & 67.19 \\
\hline
\end{tabular}

the morphology of completely montmorillonized shards with typical, tightly interwoven flakes. Characteristically, a Na-montmorillonite is more open-textured or fluffy than the Ca-montmorillonite, presumably because the $\mathrm{Na}^{+}$interlayer ion is more easily hydrated than is $\mathrm{Ca}^{2+}$ (Keller et al. 1986). The texture of these montmorillonites which display the tight "cornflake," "oak leaf," or "cellular" texture (Fig. 4a), is more typical of Ca-montmorillonites (Fig. 4b).

FTIR techniques investigate bond vibrations of the radical groups, whose spectra absorption bands appear at different frequencies. The band position is compared with the spectra noted in Gadsden (1975), and possible assignments of the representative spectra for the raw waste clay and fired samples are presented in Fig. 5. The absence of organic matter bands located at 2860 and $2930 \mathrm{~cm}^{-1}$ in the raw clay spectra from the fired sample pattern reveals another result due to the disappearance destruction of organic matter during heating, which were located at the 713 , 875,1435 , and $2514 \mathrm{~cm}^{-1}$ spectra in the raw clay record. Similarly, sulfate bands of gypsum were not detected fired sample spectra. Another noticeable difference on the major absorption band at $1000 \mathrm{~cm}^{-1}$ of the raw clay in the sample is that it shifted toward $1100 \mathrm{~cm}^{-1}$ in fired sample due to the breakup of the clay structure (bands region 900$1000 \mathrm{~cm}^{-1}$ ) and predominance of quartz (bands region $1000-1100 \mathrm{~cm}^{-1}$ ) during firing. The clay structure bands at 525, 845, 908, 933, 1380, 1405, 3645, and $3696 \mathrm{~cm}^{-1}$ are mostly "extinct" in the fired sample, while water bending and stretching at 1645 and $3446 \mathrm{~cm}^{-1}$ remain in the record of the fired sample, but these bands may also reveal water absorption from lab environment and absorption of water molecules from atmospheric air while recording the spectra.

The physical properties of the waste clay before and after firing are shown in Table 2. The bulk density of the raw waste clay was $2.21 \mathrm{~g} / \mathrm{cm}^{3}$ while after firing, it was
$0.89 \mathrm{~g} / \mathrm{cm}^{3}$. The apparent porosity of the raw clay was $6.55 \%$ while that of the fired one is $67.19 \%$.

\section{Properties of the casted mixes}

Table 3 presents the properties of the two casted mixes. In mix 1 , the fired waste clay aggregates are coarse grains ranged from 2 to $10 \mathrm{~mm}$, while mix 2 aggregates are composed of coarse grains with $10 \%$ finer ones. The concrete mixes 1 and 2 are prepared as 6:1 aggregate to cement ratio with a binder to water ratio of 0.4 . The physical and mechanical properties of the casted mixes including the bulk density and the crushed strength are summarized in Table 3. The bulk density is 0.76 and $0.90 \mathrm{~g} / \mathrm{cm}^{3}$ for mix 1 and mix 2, respectively, while the crushing strength for mix 1 and mix 2 was 25 and $45 \mathrm{~kg} / \mathrm{cm}^{2}$, respectively.

\section{Discussion}

\section{Effect of clay firing}

The effect of increasing firing temperature up to $1100{ }^{\circ} \mathrm{C}$ on crystal phases of the selected samples was studied using XRD technique (Fig. 6). It was shown that quartz, cristobalite, and hematite phases are present at $1100{ }^{\circ} \mathrm{C}$ with high liquid phases of calcium aluminium silicate binding everything in a glassy groundmass.

Table 2 indicates that the bulk density of the fired clay decreased from $2.21 \mathrm{~g} / \mathrm{cm}^{3}$ for the raw waste clay to $0.89 \mathrm{~g} / \mathrm{cm}^{3}$, while the apparent porosity increased from $6.55 \%$ for the raw waste clay to $67.19 \%$ after firing. The enormous expansion indicated by the porosity is due to the gasses generated by oxidation of the organic material contained in the raw clay, note in Fig. 5 the absence of organic matter bands from the fired sample IR pattern due to the oxidation. This expansion occurs until the surfaces of the particles have attained sufficient strength to prevent the gasses from escaping.

\section{Assessment of lightweight bricks}

To consider the blocks produced from the fired aggregates as lightweight bricks according to the British Specification No. 2028, bulk density should be between 0.55 and $1.05 \mathrm{~g} / \mathrm{cm}^{3}$. The bulk density of the concretes ranges from 0.76 to $0.90 \mathrm{~g} / \mathrm{cm}^{3}$ for the coarse type with no fine aggregates mix 1 and the coarse type with $10 \%$ fine aggregates mix 2, respectively (Table 3 ). The crushing strength of both types after curing for 28 days was

Table 3 Mix composition and properties of the prepared lightweight concrete

\begin{tabular}{|c|c|c|c|c|}
\hline \multirow{2}{*}{$\begin{array}{l}\text { Type of the fired waste clay aggregate in } \\
\text { the mixture }\end{array}$} & \multicolumn{2}{|c|}{ Mix composition (ratio by volume) } & \multirow{2}{*}{$\begin{array}{l}\text { Bulk density } \\
\left(\mathrm{g} / \mathrm{cm}^{3}\right)\end{array}$} & \multirow{2}{*}{$\begin{array}{l}\text { Crushing strength } \\
\left(\mathrm{kg} / \mathrm{cm}^{2}\right)\end{array}$} \\
\hline & Aggregate/cement ratio & Water/cement ratio & & \\
\hline $\begin{array}{l}\text { Mix } 1 \\
\text { Coarse aggregate (2-10 mm grain size) }\end{array}$ & $6: 1$ & 0.4 & 0.76 & 25 \\
\hline $\begin{array}{l}\text { Mix } 2 \\
\text { Coarse aggregate with 10\% finer particles }\end{array}$ & $6: 1$ & 0.4 & 0.90 & 45 \\
\hline
\end{tabular}




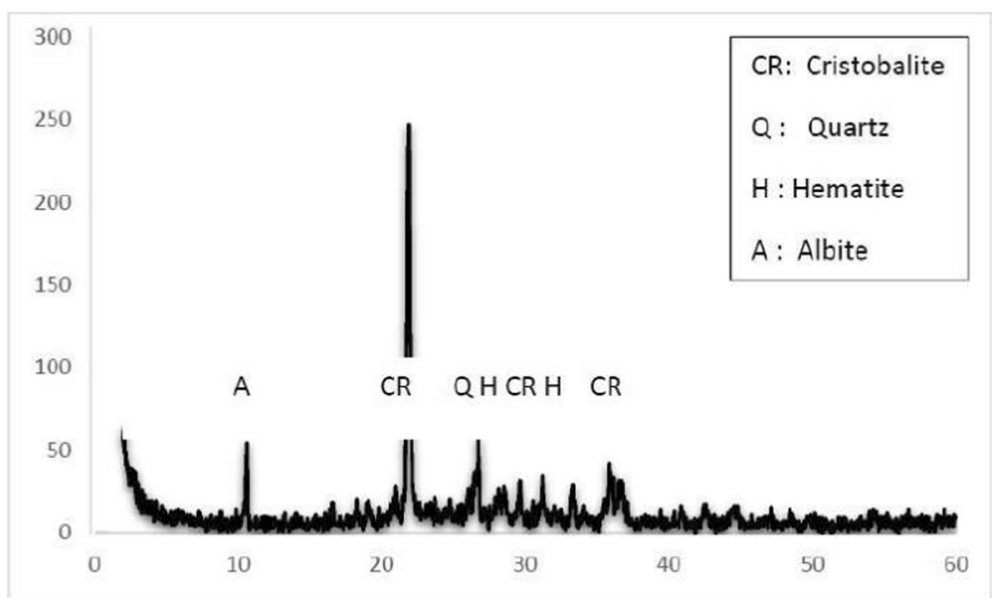

$2 \operatorname{Theta}^{\circ}$ (copper $\left.\mathrm{Cu}\right)$

Fig. 6 XRD pattern of the fired clay sample

$25 \mathrm{~kg} / \mathrm{cm}^{2}$ for coarse-grained types only and $45 \mathrm{~kg} / \mathrm{cm}^{2}$ for coarse-fine-grained types. The above results indicate that the concretes, containing the fine portion of the grain sizes, gave a higher compressive strength and a higher density than those without any fine fractions. Therefore, it is possible to produce lightweight concrete blocks of low density and relatively good strength to be utilized in modern building trend for non-loading building units and in the partition wall construction, as well as for improving the thermal insulation of buildings.

\section{Conclusions}

- The materials used in this work were waste clays from Yunis mines, which are located south of the Hamrawin area and $12 \mathrm{~km}$ from Qusseir-Safaga Asphaltic Road to the west.

- XRF, XRD, FTIR, and SEM data confirmed that the predominant mineral components present are montmorillonite, with quartz, calcite, fluorapatite, gypsum, and pyrite impurities.

- Bulk density and apparent porosity of the fired samples at $1100{ }^{\circ} \mathrm{C}$ are $0.89 \mathrm{~g} / \mathrm{cm}^{3}$ and $67.19 \%$, respectively.

- Two types of concrete were prepared using two different grain size fractions of the fired waste clay grains. The first grain type ranges from 2 to $10 \mathrm{~mm}$ with no fines while the second contains the coarse grows ( 2 to $10 \mathrm{~mm}$ ) with a $10 \%$ finer fraction.

- The bulk density of the two types of concrete ranges between $0.76 \mathrm{~g} / \mathrm{cm}^{3}$ in coarse-grained type with no fines and $0.90 \mathrm{~g} / \mathrm{cm}^{3}$ in the coarse-grained fraction with $10 \%$ fine fraction. The crushing strength of both types after curing for 28 days is $25 \mathrm{~kg} / \mathrm{cm}^{2}$ for coarse type and $45 \mathrm{~kg} / \mathrm{cm}^{2}$ for coarse and fine types.
- The thousands of small, air-filled cavities give the two types their strength and thermal insulation properties. The base material was waste clay and was fired up to $1100{ }^{\circ} \mathrm{C}$. Finally, the clay materials were mixed and molded to form lightweight concrete block products.

- The above results indicate the possibility of producing low-density and relatively high-strength concrete block products for the utilization in modern building trend for dead-load construction for partition wall construction, as well as for improving the thermal insulation of buildings.

Funding

This study was funded by the NRC project titled "Effect of soil pollution and geochemical characteristics on its productivity and its relation to electrical properties."

Availability of data and materials

The authors declare that the work data and material are available.

Authors' contributions

EAE-A, HM, and WA contributed in the field, geochemistry, mineralogy, and application works. ME contributed to the mineralogy, physical parameters, and application works. All authors read and approved the final manuscript.

Ethics approval and consent to participate

The authors declare that the work is ethically approved and consent to participate.

Consent for publication

The authors declare that the work has a consent for publication.

Competing interests

The authors declare that they have no competing interests.

\section{Publisher's Note}

Springer Nature remains neutral with regard to jurisdictional claims in published maps and institutional affiliations. 


\section{Author details}

'Geological Sciences Department, National Research Centre, Al-Behoos Street, Dokki, Cairo 12622, Egypt. ${ }^{2}$ Refractories, Ceramics and Building Materials Department, National Research Centre, Dokki, Cairo 12622, Egypt.

Received: 29 June 2018 Accepted: 6 September 2018

Published online: 03 October 2018

\section{References}

ASTM C20 (2010) Standard test methods for apparent porosity, water absorption, apparent specific gravity, and bulk density of burned refractory brick and shapes by boiling water. Annual Book of ASTM Standards, ASTM International, West Conshohocken

Bernhardt M et al (2013) Mechanical properties of lightweight aggregates. J Eur Ceram Soc 33:2731-2743

Bian Z, Miao X, Lei S, Chen SE, Wang W, Struthers S (2012) The challenges of reusing mining and mineral-processing wastes. Science 337(6095):702-703

British standard 2028 (1968) Precast concrete blocks. British Standards Institution BS 2028:1968. BSI, London, England

Burst JF (1991) The application of clay minerals in ceramics. Appl Clay Sci 5(5-6): $421-443$

Chemani H, Chemani B (2013) Valorization of wood sawdust in making porous clay brick. Sci Res Essays 8(15):609-614

Courtault B, Brand JP, Boisson G (1983) "Carbonaceous shales", Cim., Betons, plastres, Chaux, vol 39, p 740

Duchan V, Kopar T (2001) Sawdust and paper-making sludge as pore forming agents for lightweight clay bricks source. Ind Ceram 21(2):81-86

Gadsden JA (1975) Infrared spectra of minerals and related inorganic compounds. Butterworths, London

Grim RE (1962) Applied clay mineralogy. Mc Graw Hill Book Comp., Inc., New York, Toronto, London

Grim RE (1968) Clay mineralogy, 2nd edn. Mc Graw Hill Book Comp., Inc., New York, Toronto, London

Grimshaw RW (1971) The chemistry and physics of clays and other ceramic materials. Ernst Benn, London

Hanna FS, Stoops G (1977) Micromorphological description of some clayey basin irrigated soils [clay, silty clay, Egypt]. Egypt J Soil Sci. 17;1:21-33

Ismail AIM, Souaya ER, El-Hakeem AA (2016) Assessment of different shapes and grain sizes of bentonite aggregates in lightweight concretes. Interceram-Int Ceramic Rev 65(3):96-99

Ismail AIM, Souaya ER, Fathy M, El-Hakeem AA (2018) Production of lightweight concretes from pumice/bentonite mix. Geotech Geol Eng 36(1):581-588

Karaman S, Gunal H, Ersahin S (2006) Assesment of clay bricks compressive strength using quantitative values of colour components. Constr Build Mater 20:348-354

Keller WD, Reynolds RC, Inoue A (1986) Morphology of clay minerals in the smectite - to - illite conversion series by scanning electron microscopy. Clay Clay Miner 34(2):187-197

Konta J (1979) Deposits of ceramic raw materials. Ceramic MonographsHandbook of Ceramics, Verlag Schmid GmbH, Freiburg, Monograph, 1(3).

Konta J (1995) Clay and man: clay raw materials in the service of man. Appl Clay Sci 10:275-335

Mashaly AO, El-Kaliouby BA, Shalaby BN, El-Gohary AM, Rashwan MA (2016) Effects of marble sludge incorporation on the properties of cement composites and concrete paving blocks. J Clean Prod 112:731-741

Mashaly AO, Shalaby BN, Rashwan MA (2018) Performance of mortar and concrete incorporating granite sludge as cement replacement. Constr Build Mater 169:800-818

Norton FH (1969) Refractories, 4th edn. Mc Graw Hill Book Comp., Inc., New York, Toronto, London

Pelisser F, Barcelos A, Santos D, Peterson M, Bernardin AM (2012) Lightweight concrete production with low Portland cement consumption. J Clean Prod 23(1):68-74

Risdanareni P, Choiri AA, Djatmika B, Puspitasari P (2017) Effect of the use of metakaolin artificial lightweight aggregate on the properties of structural lightweight concrete. Civ Eng Dimens 19(2):86-92

Routschka G (ed) (1997) Refractory materials: pocket manual. Vulkan Verlag Essen Said R (1990) The geology of Egypt, 2nd edn. A. A. Balkeema Publishers, Rotterdam
Sargeant GK, Stone RE (1981) Inventors; Cawoods Refractories Ltd, assignee. Process for manufacturing a lightweight refractory product. United States patent US 4,307,051.

Serry MA, Hegab M, Elbana MM (1985) Lightweight clay aggregates from Wadi El- Natrun clays (Egypt). Sprechsael 118:N Y11

Youssef AM (2008) Mapping the Pliocene clay deposits using remote sensing and its impact on the urbanization developments in Egypt: case study, East Sohag area. Geotech Geol Eng 26(5):579-591

\section{Submit your manuscript to a SpringerOpen ${ }^{\circ}$ journal and benefit from:}

- Convenient online submission

- Rigorous peer review

- Open access: articles freely available online

- High visibility within the field

- Retaining the copyright to your article

Submit your next manuscript at $\boldsymbol{\nabla}$ springeropen.com 